ANADOLU, J. of AARI

ISSN: 1300-0225 (Print)

E-ISSN: 2667-6087 (Online)

2021, 31 (2): 170-174

DOI: $10.18615 /$ anadolu. 1030016

\title{
Determination of efficiency of entomopathogenic nematode Heterorhabditis bacteriophora (Rhabditida: Heterorhabditidae) on the potato tuber moth (Phthorimaea operculella (Zeller)) (Lepidoptera: Gelechiidae) under controlled conditions
}

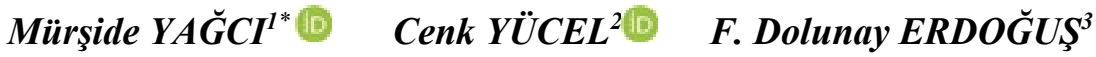 \\ 1,2,3,4 Plant Protection Central Research Institute, 06172, Yenimahalle, Ankara/TURKEY \\ ${ }^{1}$ https://orcid.org/0000-0003-2269-7649 \\ ${ }^{2}$ https://orcid.org/0000-0001-5223-9257 \\ ${ }^{3}$ https://orcid.org/0000-0001-9847-6100 \\ ${ }^{4}$ https://orcid.org/0000-0003-3145-0808 \\ ${ }^{*}$ Corresponding author (Sorumlu yazar): yagci.murside@tarimorman.gov.tr \\ Received (Geliş tarihi): 06.03.2021 Accepted (Kabul tarihi):09.09.2021
}

F. Manolya AKBULUT

\begin{abstract}
The potato tuber moth, Phthorimaea operculella (Zeller) (Lepidoptera: Gelechiidae), is an important pest of potato that causes yield losses in potato producing countries all over the world. Many management methods are available for reducing this pest populations. Chemical control methods are at the top of these. However, Entomopathogenic nematode (EPNs), can be used as a potential alternative to chemical insecticides to control potato tuber moth larvae as an eco-friendly management method. We aimed in this study to examine the efficacy of Turkish isolates of Heterorhabditis bacteriophora (TOK20) against the last instar larvae (fourth stage) of the potato tuber moth under laboratory conditions. Experiments were conducted in 150 milliliter plastic cups with sterile soil mixture. Four nematode concentrations (0, 250, 500 and 1000 IJS) were applied directly to the soil. Potato tuber moth was susceptible to different concentrations of the H. bacteriophora (TOK-20) isolate. All doses were more effective than the control (water). The most effective was the 1000 IJs concentratio, providing a high mortality rate of the last instar larvae of potato tuber moth. No statistically significant difference was observed among temperatures. These results indicated that this $\boldsymbol{H}$. bacteriophora (TOK-20) isolate is very efficient and could be used against potato tuber moth in biological control programs.
\end{abstract}

Keywords: Entomopathogenic nematodes, Phthorimaea operculella, biological control, efficiency, potato.

\section{Entomopatojen nematod Heterorhabditis bacteriophora'nın (Rhabditida: Heterorhabditidae) kontrollü koşullar altunda patates güvesi (Phthorimaea operculella (Zeller)) (Lepidoptera: Gelechiidae) üzerinde etkinliğinin belirlenmesi}

ÖZ: Patates güvesi Phthorimaea operculella (Zeller) (Lepidoptera: Gelechiidae), tüm dünyada patates üreten ülkelerde verim kayıplarına neden olan önemli bir patates zararlısıdır. Bu zararlı populasyonu azaltmak için birçok mücadele yöntemi mevcuttur. Bunların başında kimyasal mücadele yöntemleri gelmektedir. Örnek olarak, Entomopatojenik nematodlar (EPN'ler), patates güvesi larvalarını kontrol etmek için kimyasal insektisitlere alternatif ve çevre dostu bir mücadele yöntemi olarak kullanılabilir. Bu çalışmada, Türkiye'deki Heterorhabditis bacteriophora (TOK-20) izolatlarının patates güvesinin son dönem (dördüncü dönem) larvalarına karşı etkinliğinin laboratuvar koşullarında araştırılmasını amaçlanmıştır. Deneyler, steril toprak karışımı ile 150 mililitrelik plastik kaplarda yapılmıştır. Dört nematod konsantrasyonu (0, 250, 500 ve 1000 IJ) doğrudan toprağa uygulanmıştır. Patates güvesi farklı konsantrasyonlarda H. bacteriophora (TOK-20) izolatına duyarlı bulunmuştur. Tüm dozlar kontrolden (su) daha etkili çıkmıştır. En yüksek ölüm oranı en etkili doz olan 1000 IJs konsantrasyonda görülmüş olup, sıcaklıklar arasında herhangi bir istatistiki farklılık görülmemiştir. Bu sonuçlar, H. bacteriophora (TOK-20) izolatının çok etkili olduğunu ve biyolojik mücadele programlarında patates güvesine karşı mücadelede kullanılabileceğini göstermiştir.

Anahtar kelimeler: Entomopatojen nematodlar, Phthorimaea operculella, biyolojik mücadele, etkinlik, patates. 


\section{INTRODUCTION}

Potato is widely cultivated throughout the world. Potatoes are economically important especially in the food sector. According to data, potato is grown on 148 thousand ha with 5.2 million tons of production in Turkey (Anonim, 2020). Potato plants are attacked by many diseases and pests in different growth periods. Phthorimaea operculella (Zeller) (Lepidoptera: Gelechiidae) is one of the most important pests in potato-growing areas. It is an oligophagous pest. Adult females lay up to 200 eggs in small clusters. This species feeds on potatoes, tomatoes, eggplants, peppers, tobacco and weeds in Solanaceae family (Rondon, 2010). The pest survives as larva or pupa on potatoes left in storage or in the field during winter. They feed by opening galleries in the leaves and shoots in the field as well as in stored tubers (Anonim, 2008).

Today, in many countries, entomopathogenic nematodes (EPNs) are used for biological control of many insect pests (Shields et al., 1999; Laznik and Trdan, 2012; Belien, 2018). EPNs are a group of soil dwelling nematodes that parasitize insect pests. Use of these nematodes is economical and eco-friendly, since they are harmless to non-target organisms, human health and the environment (Gulcu et al., 2017). Other advantages of using EPNs is that they are capable of actively locating insect pests in cryptic habitats, and aboveground pests have no opportunity to develop coevolutionary barriers toward EPNs. EPNs can serve as an effective supplementary control as part of an integrated pest management (IPM) strategy (Odendaal et al., 2015; Belien, 2018; Gulcu et al., 2017). A few studies have investigated the effects of EPNs against potato tuber moth (Kepenekci et al., 2013; Mhatre et al., 2020; Yan et al., 2020; Orakç1, 2021).

In this study we aimed to assess the efficiency of H. bacteriophora (TOK-20) Poinar (Rhabditida: Heterorhabditidae) against the last instar larvae of the potato tuber moth under controlled conditions. Nematodes were applied to sterilized soil at three different temperatures. In addition, our aim was to determine the temperature at which nematode infection is the best.

\section{MATERIAL and METHODS}

\section{Nematode culture}

Infective juveniles of Heterorhabditis bacteriophora (TOK-20) obtained from the Plant Protection Department of Tokat Gaziosmanpaşa University, Turkey were used in this study. Infective juveniles were reared, using the last instar larvae of Galleria mellonella (L.) according to the procedures described by Kaya and Stock (1997).

\section{Rearing Galleria mellonella larvae}

Galleria mellonella larvae were reared on a special diet containing $890 \mathrm{~g}$ of flour, $222 \mathrm{~g}$ of dry baker's yeast, $500 \mathrm{~g}$ of glycerin, $500 \mathrm{~g}$ of honey, $445 \mathrm{~g}$ of milk powder and $125 \mathrm{~g}$ of beeswax. Honey and glycerin were heated and then added to flour, bran, milk powder and yeast mixture (Mohamed and Coppel, 1983). G. mellonella eggs were placed on the food medium in one liter glass jars and kept in an incubator with $16 / 8 \mathrm{hrs}$ light at $23-24{ }^{\circ} \mathrm{C}$ for 40 45 days.

\section{Rearing of entomopathogenic nematodes}

Last instar larva of G. mellonella were used to mass rear the EPN for trials. Ten larvae were placed into a $6 \mathrm{~cm}$ diameter Petri dish with lined Whatman 1 paper soaked with distilled water. A suspension of infective juveniles of nematodes were applied on the G. mellonella larvae. The lid of the Petri dish was wrapped with parafilm and placed in the incubator at $20-23{ }^{\circ} \mathrm{C}$. Larval mortality was controlled every day. Infective EPN larvae were obtained from infected $G$. mellonella larvae using the "White trap" method (White, 1927). These larvae were placed in culture flasks and kept in a refrigerator at $+10{ }^{\circ} \mathrm{C}$. In order to prevent the nematodes from losing their activity, the same process was repeated by infecting new $G$. mellonella larvae every 1-2 months and thus the cultures were renewed at the Nematology Laboratory of Directorate of Plant Protection Central Research Institute, Turkey.

\section{Rearing of potato tuber moth last stage (fourth stage) instar larvae}

The potato tuber moth was reared on infected potatoes in the Entomology Laboratory in the 
Central Plant Protection Research Institute. $P$. operculella eggs were placed on the potatoes in $15 \times 30 \mathrm{~cm}$ cylindrical plastic cups and kept in an incubator with $14 / 10 \mathrm{hrs}$ light at $25 \pm 1{ }^{\circ} \mathrm{C}$ (Golizadeh et al., 2014). Infected potatoes were kept in cups with $3-5 \mathrm{~cm}$ soil. The last stage larvae in the soil were collected for use in the experiment.

\section{Biossays}

Trials were conducted in 150 milliliter plastic pots containing a mixture of soil $(80 \%$ sand, $15 \%$ soil and $5 \%$ clay) sterilized at $121{ }^{\circ} \mathrm{C}$ (Robbins and Barker, 1974; Chen et al.,1995). The assay cups were placed in an incubator at different temperatures $\left(10,15,25^{\circ} \mathrm{C}\right)$ in the dark. Laboratory studies were carried out under laboratory conditions. There was one last instar larva in each cup. Entomopathogenic nematode concentrations (0, 250, 500 and $1000 \mathrm{IJs}$ ) were applied directly to the larva by pipette (Figure 1). Only water was added to the control plastic cups. Larval mortality was calculated after seven days. Laboratory studies were conducted with ten replicates for each concentration of EPN. The experiment was repeated three times under the same conditions on different dates.

Dead larvae were placed on a white trap and, after a week, EPN larvae were obtained from infected $P$. operculella larvae. Insect cadavers were examined in distilled water under a stereomicroscope.

\section{Statistical analyses}

The mortality data obtained in the study were first converted to percentages and then subjected to analysis of variance (ANOVA) after arc-sin transformation. Comparisons between percent mortality rate and corrected percent mortality effect rate (Abbott, 1925) means were made using Duncan Multiple Comparison Test. All statistical analyses were done using SPSS program.

\section{RESULTS and DISCUSSION}

Results were evaluated seven days after EPN inoculation on the potato tuber moth larvae. The main factors (nematode concentration and temperature) were considered and examined.
Nematode concentration interactions were statistically significant whereas temperature interactions were not significant.
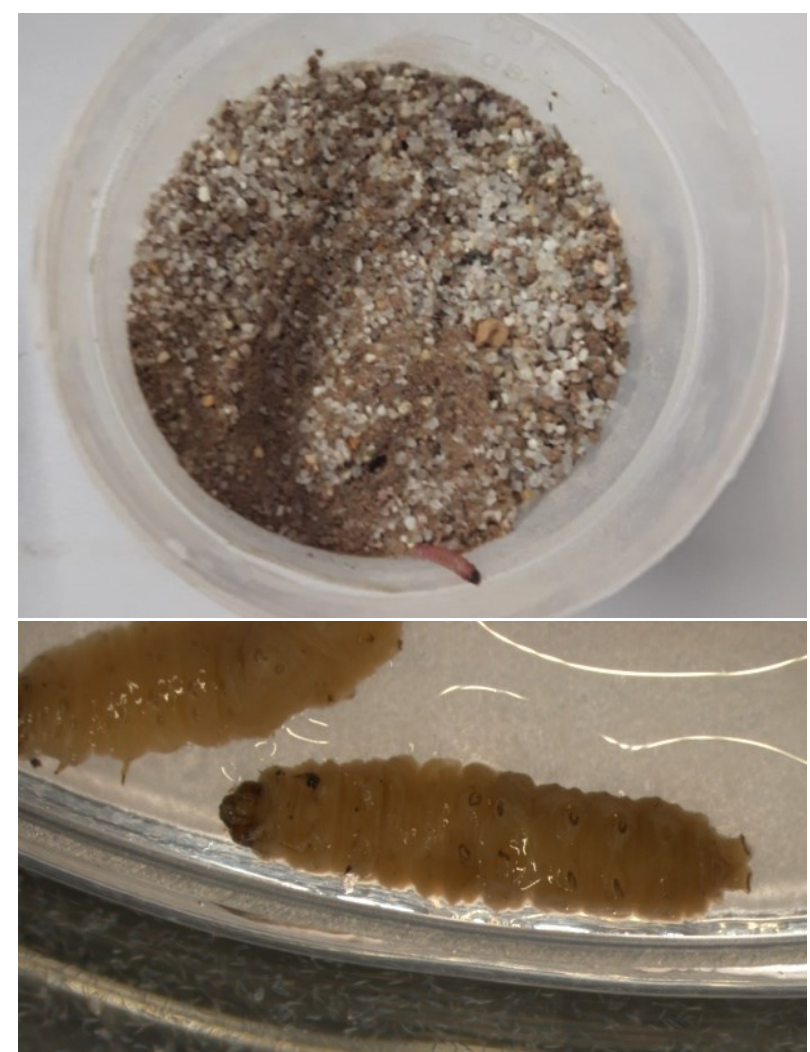

Figure 1. Entomopathogenic nematodes emerging from potato tuber moth cadaver to water.

Şekil 1. Entomopatojen nematodların patates güvesi kadavrasından suya çıkışı.

Entomopathogenic nematodes were more highly effective than the control (water). As presented in Table (1), mortality rates caused by the nematode had a general trend, i.e. their effects increased with increasing concentration $(\mathrm{P} \leq 0.05)$.

H. bacteriophora (TOK-20) had the highest effect on mortality at the highest concentration (1000 juveniles), causing a mortality rate of $70.83,80.47$ and $80.42 \%$ of potato tuber moth larvae at $10{ }^{\circ} \mathrm{C}$, $15{ }^{\circ} \mathrm{C}$ and $25{ }^{\circ} \mathrm{C}$, respectively. H. bacteriophora (TOK-20) caused the least mortality rate on $P$. operculella larvae at the 250 IJs concentrations, with $48.21,34.33$ and $32.8 \%$ mortalities of potato tuber moth larvae at $10{ }^{\circ} \mathrm{C}, 15{ }^{\circ} \mathrm{C}$ and $25{ }^{\circ} \mathrm{C}$, respectively. Although the effect of temperature on mortality rate is not statistically significant, the highest mortality rate was at $15{ }^{\circ} \mathrm{C}$ in general. 
M. YAĞCI, C. YÜCEL, F. D. ERDOĞUS, F. M. AKBULUT: DETERMINATION OF EFFICIENCY OF ENTOMOPATHOGENIC NEMATODE HETERORHABDITIS BACTERIOPHORA (RHABDITIDA: HETERORHABDITIDAE) ON THE POTATO TUBER MOTH (Phthorimaea operculella (ZELLER)) (LEPIDOPTERA: GELECHIIDAE) UNDER CONTROLLED CONDITIONS

Table 1. Mortality rate of last instar larvae of Phthorimaea operculella caused by different infective juvenile concentrations of Heterorhabditis bacteriophora (TOK-20).

Çizelge 1. Heterorhabditis bacteriophora'nın (TOK-20) farklı juvenil konsantrasyonlarında neden olduğu Phthorimaea operculella'nın son dönem larvalarının ölüm oranı.

\begin{tabular}{lccc}
\hline Concentration & \multicolumn{3}{c}{ Temperature ${ }^{\circ} \mathrm{C}$ (Sicaklik) } \\
\cline { 2 - 4 } Konsantrasyon & 10 & 15 & 25 \\
\hline $1000 \mathrm{IJs}$ & $70.83 \pm 5.73 \mathrm{a}^{*}$ & $80.47 \pm 9.77 \mathrm{a}$ & $80.42 \pm 6.93 \mathrm{a}$ \\
$500 \mathrm{IJs}$ & $52.38 \pm 2.38 \mathrm{a}$ & $57.56 \pm 1.29 \mathrm{ab}$ & $51.32 \pm 7.68 \mathrm{~b}$ \\
$250 \mathrm{IJs}$ & $48.21 \pm 15.02 \mathrm{a}$ & $34.33 \pm 8.77 \mathrm{~b}$ & $32.8 \pm 5.96 \mathrm{~b}$ \\
Control (Kontrol) & $23.33 \pm 3.33$ & $13.33 \pm 8.82$ & $16.67 \pm 6.67$ \\
\hline
\end{tabular}

*Means followed by the same letter are not statistically different according to the Duncan test $(\mathrm{P} \leq 0.05)$. Ayn harfle olan ortalamalar Duncan testine göre istatistiksel olarak farklı değildir $(\mathrm{P} \leq 0,05)$.

Our results indicate that last instar of $P$. operculella are highly susceptible to $H$. bacteriophora (TOK20). P. operculella larvae caused $80 \%$ mortality rate at $15{ }^{\circ} \mathrm{C}$ and $25{ }^{\circ} \mathrm{C}$ at $1000 \mathrm{IJs}$ concentration. Several studies have investigated the effects of EPNs on potato tuber moth. Also, in accordance with our study, Moawad et al. (2018) found that $S$. carpocapsae and $H$. bacteriophora cause death between $98-100 \%$ and these two nematode species are very effective against $P$. operculella. HassaniKakhki et al. (2013) showed that $S$. carpocapsae and $H$. bacteriophora strains (commercial and FUM7) caused the highest mortality against the larval and prepupal stage of $P$. operculella. Yan et al. (2020) evaluated different concentrations of $S$. carpocapsae for control of $2^{\text {nd }}, 3^{\text {rd }}$, and $4^{\text {th }}$ instar $P$. operculella under laboratory conditions. They determined that the fourth instar stage was the most susceptible. Mhatre et al. (2020) reported that Steinernema cholashanense caused the greater mortality in the fourth-instar larval stage $(100 \%)$ compared to the pupae (30\%). Kepenekci et al. (2013) investigated the efficacy of $S$. carpocapsae, $S$. feltiae and H. bacteriophora, which are detected

\section{REFERENCES}

Abbott, W.S. 1925. A method of computing the effectiveness of an insecticide. Journal of Economic Entomology 18: 265-267.

Anonim. 2008. Zirai Mücadele Teknik Talimatları. Cilt.3. Ankara.

Anonim. 2020. https://data.tuik.gov.tr/Bulten/ Index?p= Bitkisel-Uretim-Istatistikleri-2020-33737.

Belien, T. 2018. Entomopathogenic nematodes as biocontrol agents of insect pests in orchards. CAB Reviews 13, No. 058. in Turkey, against potato moth $P$. operculella. In that study, S. carpocapsae and H. bacteriophora caused $96 \%$ and $80 \%$ larval mortality, respectively, at $25{ }^{\circ} \mathrm{C}$ and $1000 \mathrm{IJs}$ concentration. As a result of the study, S. carpocapsae (Black Sea isolate) was found to have the highest effect against potato tuber moth.

Our results indicated that $H$. bacteriophora (TOK20) has good potential for the management of $P$. operculella. Future work is necessary to determine the efficacy of entomopathogenic nematodes against $P$. operculella under field conditions. If favorable results are obtained, $H$. bacteriophora could be used for control of the potato tuber moth in integrated pest management programs in potatogrowing regions.

\section{ACKNOWLEDGEMENTS}

The author would like to thank Prof. Dr. İlker KEPENEKCI (Plant Protection Department of Tokat Gaziosmanpaşa University) for providing the entompathogenic nematode material.
Chen, S.Y, D.W. Dickson and D.J. Mitchell. 1995. Effects of soil treatments on the survival of soil microorganisms. J Nematol 27(4S):661-663.

Golizadeh, A., N. Esmaeili, J. Razmjou, and H. RafieeDastjerdi. 2014. Comparative life tables of the potato tuberworm, Phthorimaea operculella, on leaves and tubers of different potato cultivars. Journal of Insect Science 14 (42): 1-11.

Gulcu, B., H. Cimen, R.K. Raja, and S. Hazir. 2017. Entomopathogenic nematodes and their mutualistic 
bacteria: their ecology and application as microbial control agents. Biopestic Int1. 3 (2), 79-112.

Hassani-Kakhki, M., J. Karimi, and M. Hossein. 2013. Efficacy of entomopathogenic nematodes against potato tuber moth, Phthorimaea operculella (Lepidoptera: Gelechiidae) under laboratory conditions. Biocontrol Science and Technology 23: 146-159.

Kaya, H.K., and S.P. Stock. 1997. Techniques in insect nematology. pp. 281-324. In: L. Lacey (Ed.). Manual of Techniques in Insect Pathology. Academic Press, San Diego, California, USA.

Kepenekci, İ., A. Tülek, M. Alkan and S. Hazir. 2013. Biological control potential of native entomopathogenic nematodes against the potato tuber moth, Phthorimaea operculella (Zeller) (Lepidoptera: Gelechiidae) in Turkey. Pakistan Journal of Zoology 45(5): 1415-1422.

Laznik, Ž., and S. Trdan. 2012. Entomopathogenic nematodes (Nematoda: Rhabditida) in Slovenia: from tabula rasa to implementation into crop production systems. pp. 627-656. In: F. Perveen (Ed.). Insecticides - Advances in Integrated Pest Management. Rijeka: Intech.

Mhatre, P.H., J. Patil, V. Rangasamy, K.L. Divya, S. Tadigiri, G. Chawla, A. Bairwa, and E.P. Venkatasalam. 2020. Biocontrol potential of Steinernema cholashanense (Nguyen) on larval and pupal stages of potato tuber moth, Phthorimaea operculella (Zeller). Journal of Helminthology Volume 94, 2020, e188. DOI: https://doi.org/10.1017/S0022149X20000723.

Moawad, S.S., M.M.E. Salah, H.M. Metwally, I.M. Ebadah, and Y.A. Mahmoud. 2018. Protective and curative treatments of entomopathogenic nematodes against the potato tuber moth, Phthorimaea operculella (Zell.). Bioscience Research 15(3): 2602-2610.

Mohamed, M.A., and H.C. Coppel. 1983. Mass rearing of the greater wax moth Galleria melonella (Lepidoptera: Galleridae) for small-scale laboratory. The Great Lakes entomologist 16 (4) 139-141.

Odendaal, D, M.F. Addison, and P. Antoinette. 2015. Entomopathogenic nematodes for the control of the codling moth (Cydia pomonella L.) in field and laboratory trials. Journal of Helminthology 1(5):1-9.
Orakçı, M. 2021. Patates Güvesi [Phthorımaea Operculella (Zeller) (Lepıdoptera: Gelechıdae]'ne karşı Türkiye ve Kırgizistan'dan elde edilen bazı entomopatojen nematodların sera-saksı denemeleriyle etkinliğinin araştırılması. Yüksek lisans tezi. Tokat Gaziosmanpaşa Üniversitesi

Robbins, R.T. and K.R. Barker. 1974. The effect of soil type, particle size, temperature, and moisture on reproduction of Belonolaimus longicaudatus. Journal of Nematology 6:1-6.

Rondon, S.I. 2010. The potato tuberworm: a literature review of 1ts biology, ecology and control. J.pot Res 87:149166.

Shields, E.J., A. Testa, J.M. Miller, K.L. Flanders. 1999. Field efficacy and persistence ofthe entomopathogenic nematodes Heterorhabditis bacteriophora 'Oswego' and H.bacteriophora ' $\mathrm{NC}$ ' on Alfalfa snout beetle larvae (Coleoptera: Curculionidae). Environmental Entomology 28: 128-136.

White, G.F. 1927. A method for obtaining infective nematode larvae from cultures. Science 66: 302-303.

Yan J.J., S.C. Sarkar, R.X. Meng, R. Stuart, and Y.L. Gao. 2020. Potential of Steinernema carpocapsae (Weiser) as a biological control agent against potato tuber moth, Phthorimaea operculella (Zeller) (Lepidoptera: Gelechiidae). Journal of Integrative Agriculture 19(2): 389-393. 